\title{
Pontophaedusa funiculum (Mousson, 1856) (Gastropoda: Eupulmonata: Clausiliidae) lived in captivity for 15 years
}

\author{
BARNA PÁLl-Gergely \\ Centre for Agricultural Research, Plant Protection Institute, Eötvös Loránd Research Network, Herman Ottó út 15. \\ Budapest 1022, Hungary, e-mail: pallgergely2@gmail.com, (1) https://orcid.org/0000-0002-6167-7221
}

\author{
Páll-Gergely B., 2021: Pontophaedusa funiculum (Mousson, 1856) (Gastropoda: Eupulmonata: Clausiliidae) \\ lived in captivity for 15 years. - Malacologica Bohemoslovaca, 20: 35-36. \\ https://doi.org/10.5817/MaB2021-20-35 \\ Publication date: 6. 8. 2021.
}

\begin{abstract}
A specimen of the clausiliid snail Pontophaedusa funiculum (Mousson, 1856) was kept alive for 15 years after it was collected as an adult. This is the longest direct observation of the lifespan in the Clausiliidae, and one of the longest in all land snails.
\end{abstract}

Key words: lifespan, land snail, life history, door snail

On my 20th birthday (20 May 2006), I collected ten adult and two juvenile living individuals of the clausiliid land snail Pontophaedusa funiculum (Mousson, 1856) in northeastern Turkey (Artvin Prov., Borçka, left side of the Çoruh River downstream of the Borçka Dam, $41^{\circ} 20.914^{\prime} \mathrm{N}, 41^{\circ} 40.518^{\prime} \mathrm{E}, 220 \mathrm{~m}$ a.s.1.). This species was ideal to observe their life-history traits because it was easy to keep them alive for years. Similarly to other members of the Serrulinini (see Uit DE WeERD \& GitTEnBERger 2013), Pontophaedusa snails live inside decaying logs that would provide a stable level of humidity and temperature. Under 'laboratory' conditions, this can be imitated by a closed plastic box with wet tissue paper. Besides that, I just gave them eggshells, and occasionally (ca. once a month) slices of carrot and cucumber. This seemingly poor treatment was sufficient for them, as indicated by the many eggs they laid during the past 15 years, and the constantly increasing population size. In the first few years, among others, I observed their mode of reproduction, the decollation process, and the formation of the clausiliar apparatus (PÁLl-Gergely \& NÉMeth 2008, PÁlL-Gergely 2010). Probably the most important finding was that Pontophaedusa is the only known clausiliid species that lays hard-shelled eggs (SuLIKOWSKA-DrozD et al. 2020; Mamos et al. 2021). Since my papers have been published, I kept a single specimen I originally collected in the nature in a separate small box, and all other adults and juveniles born in captivity in another, large box. In July 2021 I realized that while the many snails were happily crawling on the wet tissue paper in the large box, the little box was completely dried out and the specimen (Fig. 1) died of dehydration. This means that this specimen was collected as already an adult snail in May 2006, and was kept alive until June 2021. Moreover, its death was clearly caused by my carelessness, not the natural end of its life.
Although probably all slugs and most small land snails have short (ca. one year) life, lifespans, over 10 years for terrestrial molluscs is not without exception (HELLER 1990). As for Clausiliidae, there are also reports of similarly long lifespans. Based on the shell growth rate of a Cristataria genezarethana (Tristram, 1865) population, Heller \& Dolev (1994) estimated a lifespan of at least 16 years. Vestia gulo (E. A. Bielz, 1859), Vestia turgida (Rossmässler, 1836), and Phaedusa paviei (Morlet, 1893) were also kept alive in a laboratory for at least 10 years, and the specimens were either preserved or were brought back to their original collection site without waiting for their natural death (ANNA SulikowsKA-DrozD, pers. comm., July 2021). However, while the Cristataria snails are active only for a few weeks yearly, Vestia specimens underwent hibernation in the laboratory, the Pontophaedusa individuals were found crawling practically every time I opened their boxes, making the ratio of active period per lifespan of the latter species considerably longer than those of the Cristataria and Vestia species. Other published records also indicate that clausiliids generally live longer. For example, the lifespan of Vestia elata (Rossmässler, 1836) is at least 8 years in natural habitat (PIECHOCKI 1982), that of Balea perversa (Linnaeus, 1758 ) is at least 7 years in captivity (WIRTH et al. 1997), and species of the genus Albinaria also live for at least 7 years in natural habitats (GIOKAS \& MyLONAS 2002). HELLER (1990) observed that land snails inhabiting unstable habitats, such as deserts, tend to have a longer lifespan compared to those living under more stable environmental conditions. Although this may be true to some extent, here we provide an example of the contrary. Namely, a species naturally living in a stable environment (inside decaying $\log$ in a subtropical humid forest without cold winters) can also have a surprisingly long lifespan. 


\section{Acknowledgements}

I am grateful to Miklós Szekeres for his help in writing the manuscript, and Anna Sulikowska-Drozd for her unpublished information about clausiliid species kept by her.

\section{References}

Giokas S. \& Mylonas M., 2002: Spatial distribution, density and life history in four Albinaria species (Gastropoda, Pulmonata, Clausiliidae). - Malacologia, 44: 33-46.

Heller I., 1990: Longevity in molluscs. - Malacologia, 31: 259-295.

Heller J. \& Dolev A., 1994: Biology and population dynamics of a crevice-dwelling landsnail, Cristataria genezarethana (Clausiliidae). - Journal of Molluscan Studies, 60(1): 33-46. https://doi.org/10.1093/mollus/60.1.33

Mamos T., Uit de Weerd D., von Oheimb V. P. \& SulikowsKa-DrozD A., 2021: Evolution of reproductive strategies in the species-rich land snail subfamily Phaedusinae (Stylommatophora: Clausiliidae). - Molecular Phylogenetics and Evolution, 158: 107060. https://doi.org/10.1016/j.ympev.2020.107060

PÁll-Gergely B., 2010: Additional information on the reproductive biology and development of the clausilial apparatus in Pontophaedusa funiculum (Mousson, 1856) (Gastropoda, Pulmonata, Clausiliidae, Phaedusinae). - Malacologica Bohemoslovaca, 9: 1-4.

PÁll-Gergely B. \& NÉMeth L., 2008: Observations on the breeding habits, shell development, decollation, and reproductive anatomy of Pontophaedusa funiculum (Mousson, 1856) (Gastropoda, Pulmonata, Clausiliidae, Phaedusinae). - Malacologia Bohemoslovaca, 7: 11-14.

Piechocki A., 1982: Life cycle and breeding biology of Vestia elata (Rossm.) (Gastropoda, Clausiliidae). - Malacologia, 22: 219-223.

SulikowsKa-Drozd A., Duda P. \& JaniszewsKa K., 2020: Micro-CT screening of old shell collections helps to understand the distribution of viviparity in the highly diversified clausiliid clade of land snails. - Scientific Reports, 10: 60. https://doi. org/10.1038/s41598-019-56674-7

Uit De WeErd D. R. \& GitTenberger E., 2013: Phylogeny of the land snail family Clausiliidae (Gastropoda: Pulmonata). Molecular Phylogenetics and Evolution, 67: 201-216. https:// doi.org/10.1016/j.ympev.2013.01.011

WirTh T., BAUR A. \& BAUR B., 1997: Mating system and genetic variability in the simultaneously hermaphroditic terrestrial gastropod, Balea perversa on the Baltic island of Öland, Sweden. - Hereditas, 126: 199-209. https://doi.org/10.1111/j.16015223.1997.00199. $\mathrm{x}$

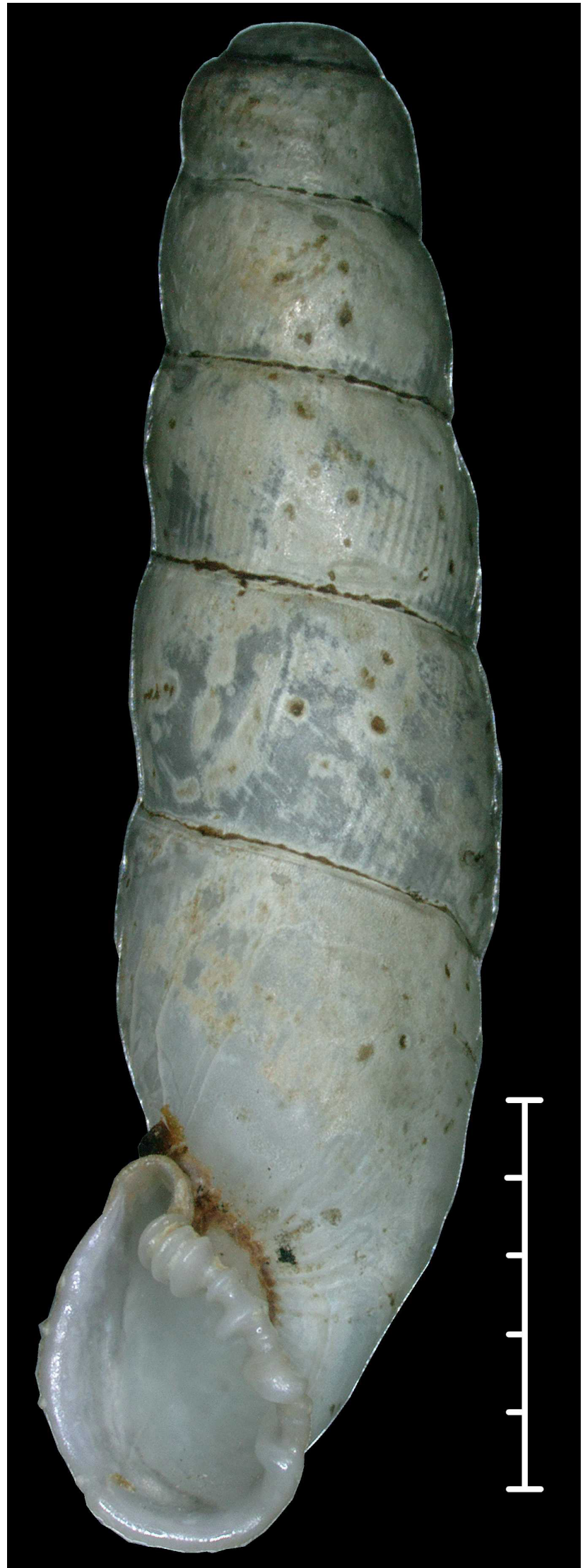

Fig. 1. The Pontophaedusa funiculum (Mousson, 1856) individual kept alive for 15 years. Photo was taken after the snail's death. Scale represents $5 \mathrm{~mm}$. 